\title{
Organic geochemical characteristics of bark coal in Changguang area: evidence from aromatic hydrocarbons
}

\author{
Yuhan Lin $^{1} \cdot$ Shaoqing Wang ${ }^{1}$ Yuming Sha ${ }^{1} \cdot$ Kun Yang $^{1}$
}

Received: 3 July 2019/Revised: 20 November 2019/Accepted: 14 May 2020/Published online: 1 June 2020

(C) The Author(s) 2020

\begin{abstract}
Seven coal samples were collected from Changguang area, a typical bark coal field in Zhejiang Province, China. The organic geochemical characteristics and depositional environment of bark coal were studied by Rock-Eval pyrolysis, gas chromatography (GC), and gas chromatography-mass spectrometry (GC-MS) analysis. The results show that all samples are type II kerogen. The values of total organic carbon (TOC), potential yield $\left(\mathrm{S}_{1}+\mathrm{S}_{2}\right)$, and hydrogen index of these samples ranged from $65.80 \mathrm{wt} \%-87.00 \mathrm{wt} \%, 170.43-232.89 \mathrm{mg} \mathrm{HC} / \mathrm{g}$, and 234-295 $\mathrm{mg} \mathrm{HC} / \mathrm{g}$ TOC, respectively. In aromatic hydrocarbons compounds of bark coal samples, the phenanthrene series occupy the largest proportion (43.48\%$53.74 \%)$, followed by the dibenzothiophens $(7.33 \%-16.53 \%)$. The distributions of naphthalenes, diphenyls, and chrysene of the samples indicate the source inputs are mainly derived from terrestrial higher plants. Furthermore, the ratios of naphthalene and phenanthrene series compounds reveal the samples are in the mature stage. Some biomarkers $(\mathrm{Pr} / \mathrm{Ph}$ and $\mathrm{C}_{35} / \mathrm{C}_{31-35}$ homohopane), aromatic hydrocarbons (fluorene, dibenzofuran and dibenzothiophene), and high inertinite contents (14.7\%-41.8\%) suggest that bark coal was formed under relatively oxic conditions and was influenced by marine or brackish lakes environment.
\end{abstract}

Keywords Bark coal · Aromatic hydrocarbon · Organic geochemistry · Maturity

\section{Introduction}

Bark coal is a special humic coal and was first reported by Hsieh (1933). In China, bark coals are mainly located in Leping area of Jiangxi Province, Changguang area of Zhejiang Province, and Shuicheng area of Guizhou Province (Sun 2002). Typical bark coal is often characterized as high hydrogen content, high sulfur content, high fusibility, high swelling ability, and high tar yield (Hsieh 1933; Dai et al. 1984; Ren et al. 1963; Han et al. 1996). The major maceral composition of bark coal is the barkinite. However, the term "barkinite" has not been

Shaoqing Wang

wangzq@cumtb.edu.cn

1 College of Geoscience and Surveying Engineering, China University of Mining and Technology, Beijing, Beijing 100083, China recognized by the International Committee for Coal and Organic Petrology (ICCP). Barkinite is often used as suberinite or cutinite (Han et al. 1983; Dai et al. 1984).

It was reported that bark coal was deposited under brackish and turbulent environment (Chen 1995). Besides, based on the value of $\mathrm{pH}$ and the ratio of $\mathrm{Sr} / \mathrm{Ba}$, the coalforming environment of bark coal was under weakly alkaline and strong reducing conditions. The source material of barkinite maybe come from psaronius, pteridosperm, the root of giantopteris plants (Chen and Chen 1996), or from lepidodendron or other plants (Yan and Li 1958; Wang et al. 1998). By now, the depositional environment and source materials of bark coal is still in vague.

There are few reports published about the aromatic hydrocarbon geochemistry of bark coal. However, aromatic hydrocarbon has a strong resistance to biodegradation, and play significant roles in depositional environment and organic matter evolution. Furthermore, coal petrology study is also widely used to instruct the coal formation 
environment (Singh et al. 2017; Ameh 2019). So, in this work, in order to further discuss the depositional environment of bark coal, the characteristics of coal petrology and saturated and aromatic hydrocarbons in bark coal were discussed.

\section{Samples and experiments}

A total of 7 bark coal samples were collected from the $\mathrm{C}_{2}$ coal seam of 6012 mining faces at six coal mines in Changguang, Zhejiang Province, China. The average depth of the working faces is about 612 meters, and the coal seam in the sampling position is 1.65 meters in thickness. Samples were marked as CG2-1, CG2-2, CG2-3, CG2-4, CG2-4, CG2-6, CG2-7. CG2-3 was collected as the parting sample. Proximate and ultimate analysis were performed following the China National Standard of GB/T 307322014 (2014) and GB/T 31391-2015 (2015), separately. Rock-Eval pyrolysis and determination of total organic carbon were conducted according to China National Standard of GB/T 18602-2012 (2012) and GB/T 191452003 (2003), respectively. In the Rock-Eval pyrolysis experiment, the initial temperature of pyrolysis is at $300{ }^{\circ} \mathrm{C}$ (holding on $3 \mathrm{~min}$ ), and then the temperature rose at a rate of $25^{\circ} \mathrm{C} / \mathrm{min}$ to $800{ }^{\circ} \mathrm{C}$. Gas chromatographic (GC) analysis was performed on an Agilent gas chromatograph with a flame ionization detector (FID). Gas chromatographymass spectrometry (GC-MS) was carried out on a DSQII 08070173 mass spectrometer, equipped with a trace GC Ultra gas chromatograph. GC and GC-MS were determined following standards of SY/T 5779-2008 (2008) and GB/T 18340-2010 (2010) respectively.

\section{Results and discussion}

\subsection{Basic characteristics}

The basic properties of the samples used are listed in Table 1. As shown in Table 1, the volatile matter yields of samples are generally high, ranging from $34.04 \%$ to $39.85 \%$. The hydrogen contents range from $5.41 \%$ to $6.05 \%$, which is consistent with the characteristic of high hydrogen content in bark coal based on previous studies (Ren et al. 1963; Han et al. 1996). The samples are mainly composed of inertinite and liptinite, which contribute $14.7 \%-41.8 \%$ and $54.3 \%-83.3 \%$ of the total, respectively. Barkinite is the major maceral composition in liptinite and CG2-5 sample have the largest barkinite content reaching $83.3 \%$. The difference between barkinite and other macerals can be easily observed under white light irradiation are shown in Fig. 1. The barkinite typically occur together with inertodetrinite and macrinite (Fig. 1a-c). The mean maximum vitrinite reflectance of the samples is with an average of $0.90 \%$.

\subsection{Hydrocarbon-generation potential analysis}

\subsubsection{Type of organic matter}

The type of organic matter can be divided into Type I, Type $\mathrm{II}_{1}$, Type $\mathrm{II}_{2}$, and Type III (Yang et al. 1981). The ratio values of $\mathrm{O} / \mathrm{C}$ and $\mathrm{H} / \mathrm{C}$ atomic of the samples are in the range of $0.03-0.06$ and $0.76-0.87$, separately. As described in Fig. 2, all samples are dropped into the junction of Type $\mathrm{II}_{1}-$ Type $\mathrm{II}_{2}$ kerogen field.

\subsubsection{Maturity of organic matter}

The results from Rock-Eval pyrolysis of the samples used are listed in Table 2. The mean maximum vitrinite reflectance $\left(R_{\mathrm{o}, \max }\right)$ and the $\mathrm{S}_{2}$ peak at its maximum pyrolysis temperature $\left(T_{\max }\right)$ are common parameters to evaluate organic matter maturity. The mean values of $R_{\mathrm{o}, \max }$ (Table 1) and $T_{\max }$ (Table 2) for 6 samples are with an average of $0.90 \%$ and $449{ }^{\circ} \mathrm{C}$, respectively, indicating CG2 samples are in the mature stage (Hunt 1996).

\subsubsection{Organic matter abundance}

The pyrolysis parameters and total organic carbon (TOC) can be used to evaluate the hydrocarbon-generation potential of organic matter in source rocks. From Table 2, TOC values range from $65.80 \mathrm{wt} \%$ to $87.00 \mathrm{wt} \%$, corresponding with the potential yields $\left(\mathrm{S}_{1}+\mathrm{S}_{2}\right)$ ranging from 170.43 to $232.89 \mathrm{mg} \mathrm{HC} / \mathrm{g}$, and the hydrogen index (HI) from 234 to $295 \mathrm{mg} \mathrm{HC} / \mathrm{g}$ TOC. These parameters indicate that these coal samples have good hydrocarbon-generation potential.

\subsection{Aromatic hydrocarbons}

\subsubsection{Aromatic hydrocarbons composition and content}

Aromatic hydrocarbons are good indicators to instruct the sedimentary environment, source materials, and degree of thermal evolution. The aromatic spectra obtained from GC-MS analyses are shown in Fig. 3. The relative abundance of some aromatic compounds were detected from aromatic hydrocarbons, including naphthalenes, phenanthrenes, biphenyls, fluorenes, dibenzofurans, dibenzothiophens, chrysene, and benzopyrenes (Table 3). From Table 3, phenanthrene series compounds occupy the largest proportion of $43.48 \%-53.74 \%$ in the total aromatic hydrocarbon contents, with an average of $47.28 \%(n=6)$. 
Table 1 Basic characteristics of samples used

\begin{tabular}{|c|c|c|c|c|c|c|c|c|c|c|}
\hline \multirow[t]{2}{*}{ Sample } & \multicolumn{3}{|c|}{ Proximate analysis $(\%)$} & \multicolumn{3}{|c|}{ Ultimate analysis (daf, \%) } & \multicolumn{3}{|c|}{ Maceral composition (dmmf, \%) } & \multirow[t]{2}{*}{$R_{\mathrm{o}}(\%)$} \\
\hline & $M_{\mathrm{ad}}$ & $A_{\mathrm{d}}$ & $V_{\text {daf }}$ & $\mathrm{C}$ & $\mathrm{H}$ & $\mathrm{O}^{*}$ & $\mathrm{~V}$ & I & $\mathrm{Ba}$ & \\
\hline CG2-1 & 0.62 & 6.34 & 34.04 & 85.47 & 5.41 & 4.70 & 3.9 & 41.8 & 54.3 & 0.90 \\
\hline CG2-2 & 0.70 & 8.58 & 35.97 & 85.22 & 5.60 & 3.86 & 0.5 & 22.5 & 77.0 & 0.91 \\
\hline CG2-4 & 1.58 & 16.81 & 34.78 & 81.94 & 5.40 & 6.53 & 2.4 & 33.0 & 64.6 & 0.91 \\
\hline CG2-5 & 0.72 & 24.11 & 39.85 & 82.55 & 6.05 & 6.26 & 2.0 & 14.7 & 83.3 & 0.90 \\
\hline CG2-6 & 0.52 & 13.73 & 35.17 & 84.53 & 5.65 & 5.41 & 2.0 & 22.7 & 75.3 & 0.90 \\
\hline CG2-7 & 0.52 & 14.03 & 35.01 & 85.05 & 5.65 & 5.13 & 1.8 & 27.9 & 70.4 & 0.90 \\
\hline
\end{tabular}

$M$ : moisture; $A$ : ash yield; $V$ : volatile matter; ad: air dry basis; d: dry basis; daf: dry and ash-free basis; dmmf: dry mineral-matter-free basis; C: carbon; H: hydrogen; O: oxygen; V: vitrinite; I: inertinite; Ba: barkinite; $R_{\mathrm{o}}$ : mean maximum vitrinite reflectance; *: by difference
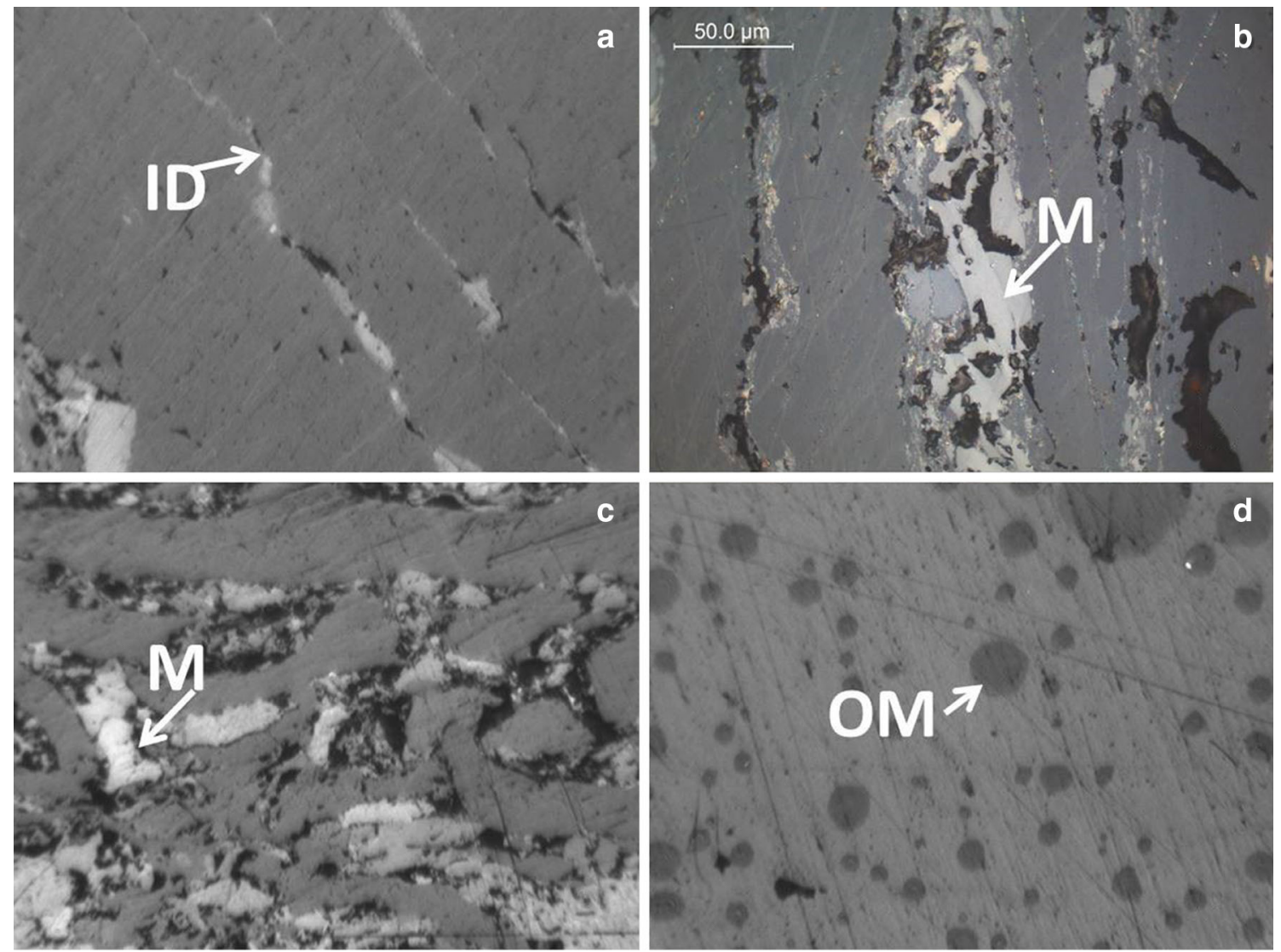

Fig. 1 Photomicrographs of occurrence of barkinite with other macerals of samples. a barkinite with inertodetrinite (ID); b, $\mathbf{c}$ barkinite with macrinite (M); d oil matter (OM) in barkinite. (These photos were observed under white light irradiation)

Followed by the content of F-OF-SF series and naphthalene series, ranging from $8.41 \%-19.63 \%$ and $5.49 \%-$ $11.91 \%$, separately.

\subsubsection{Characteristics of aromatic hydrocarbons}

3.3.2.1 Naphthalene series The naphthalene series can be used for suggesting source characterization, sedimentary condition and maturity assessment (Powell and Boreham
1994). From Table 3, the naphthalene series have an average content of $9.34 \%$, indicating the source input of CG2 samples may be come from the a mixed of lower aquatic plants and higher terrestrial plants, but mainly higher plants. In addition, the relatively high naphthalene contents also illustrate the seawater influence during the depositional process.

1,2,5-trimethylnaphthalene $(1,2,5-\mathrm{TMN})$ is an isomer of trimethylnaphthalene (TMN), converted from pentacyclic 


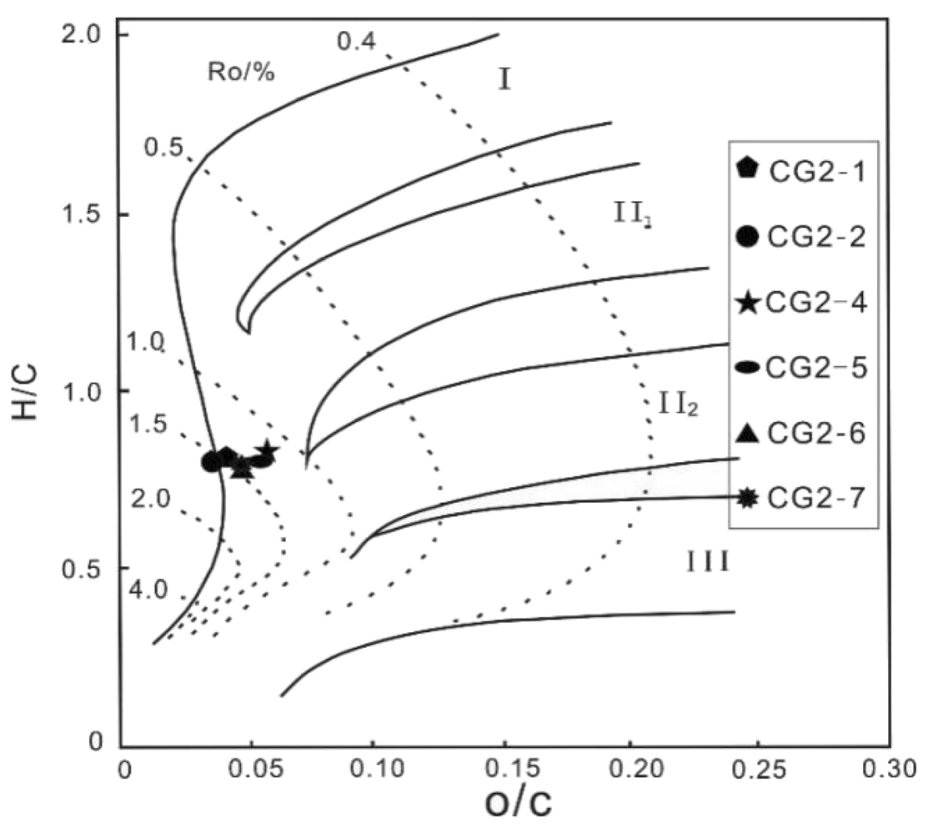

Fig. 2 The O/C and H/C correlation diagram of CG2 samples. Modified from Yang et al. (1981)

Table 2 Rock-Eval parameters of the samples used

\begin{tabular}{|c|c|c|c|c|c|c|}
\hline Sample & $T_{\max }\left({ }^{\circ} \mathrm{C}\right)$ & $\mathrm{S}_{1}(\mathrm{mg} / \mathrm{g})$ & $\mathrm{S}_{2}(\mathrm{mg} / \mathrm{g})$ & $\mathrm{S}_{1+} \mathrm{S}_{2}(\mathrm{mg} / \mathrm{g})$ & TOC (wt $\%)$ & $\mathrm{HI}(\mathrm{mg} / \mathrm{g})$ \\
\hline CG2-1 & 447 & 17.87 & 215.02 & 232.89 & 84.80 & 254 \\
\hline CG2-2 & 444 & 19.43 & 212.98 & 232.41 & 87.00 & 245 \\
\hline CG2-4 & 450 & 15.57 & 154.86 & 170.43 & 66.20 & 234 \\
\hline CG2-5 & 449 & 15.46 & 194.22 & 209.68 & 65.80 & 295 \\
\hline CG2-6 & 451 & 17.17 & 190.12 & 207.29 & 72.20 & 263 \\
\hline CG2-7 & 450 & 14.06 & 196.47 & 210.53 & 65.80 & 287 \\
\hline
\end{tabular}

TOC, total organic carbon; $\mathrm{S}_{1}$, free hydrocarbon; $\mathrm{S}_{2}$, pyrolysis hydrocarbon; $\mathrm{S}_{1}+\mathrm{S}_{2}$, potential yield; $T_{\max }$ : the $\mathrm{S}_{2}$ peak at its maximum pyrolysis temperature; HI, hydrogen index

triterpenes through degradation and rearrangement. The ratio of $1,2,5-\mathrm{TMN} / 1,3,6-\mathrm{TMN}$ is lower than 0.30 in marine crude oil, but in continental crude oil, the ratio is higher than 0.30 (Zhu et al. 1998). The ratios of 1,2, 5-TMN/1,3, 6-TMN for CG2 samples ranging from 1.28 to 2.21 , suggesting CG2 samples were deposited under the influence of marine. The main source inputs of CG2 sample are from terrestrial higher plants.

Methylnaphthalene ratio (MNR) is another maturity index in alkylated naphthalenes compounds. The average value of MNR in the samples are $0.86(n=4)$ (Table 4). The values of trimethylnaphthalene ratio $1\left(\mathrm{TNR}_{1}\right)$ and trimethylnaphthalene ratio $2\left(\mathrm{TNR}_{2}\right)$ are in the range of $0-0.58$ and $0.32-1.67$, separately. These results imply the thermal maturities of the samples are in the mature stage. The distribution of trimethylnaphthalene ratio (TMNr) and tetramethylnaphthalene ratio (TeMNr) also can reflect the degree of organic matter thermal evolution. The values of $\mathrm{TMNr}$ and $\mathrm{TeMNr}$ of the samples used range from $0 \%-$
$0.32 \%$ and $0.55 \%-0.60 \%$, respectively, indicating the thermal evolution degrees of the samples are in the mature stage.

3.3.2.2 Phenanthrene series The phenanthrene series also occupy a large proportion in the aromatic hydrocarbons. Radke et al. (1982) proposed that the methylphenanthrene index (MPI), commonly used as a maturity indicator, has good linear relationship with the vitrinite reflectance. The values of $\mathrm{MPI}_{1}$ are in the range of 0.59-0.84. The methylphenanthrene ratio $F_{1}$ and $F_{2}$ of the samples range from $0.34-0.37$ and $0.13-1.45$, respectively, indicating the samples are in the mature stages (Kvalheim et al. 1987), which is consistent with the results from naphthalenes.

3.3.2.3 F-OF-SF series $\mathrm{F}-\mathrm{OF}-\mathrm{SF}$ series include fluorene $(\mathrm{F})$, dibenzofuran $(\mathrm{OF})$ and dibenzothiophene (SF), which are good indicators to instruct the sedimentary 


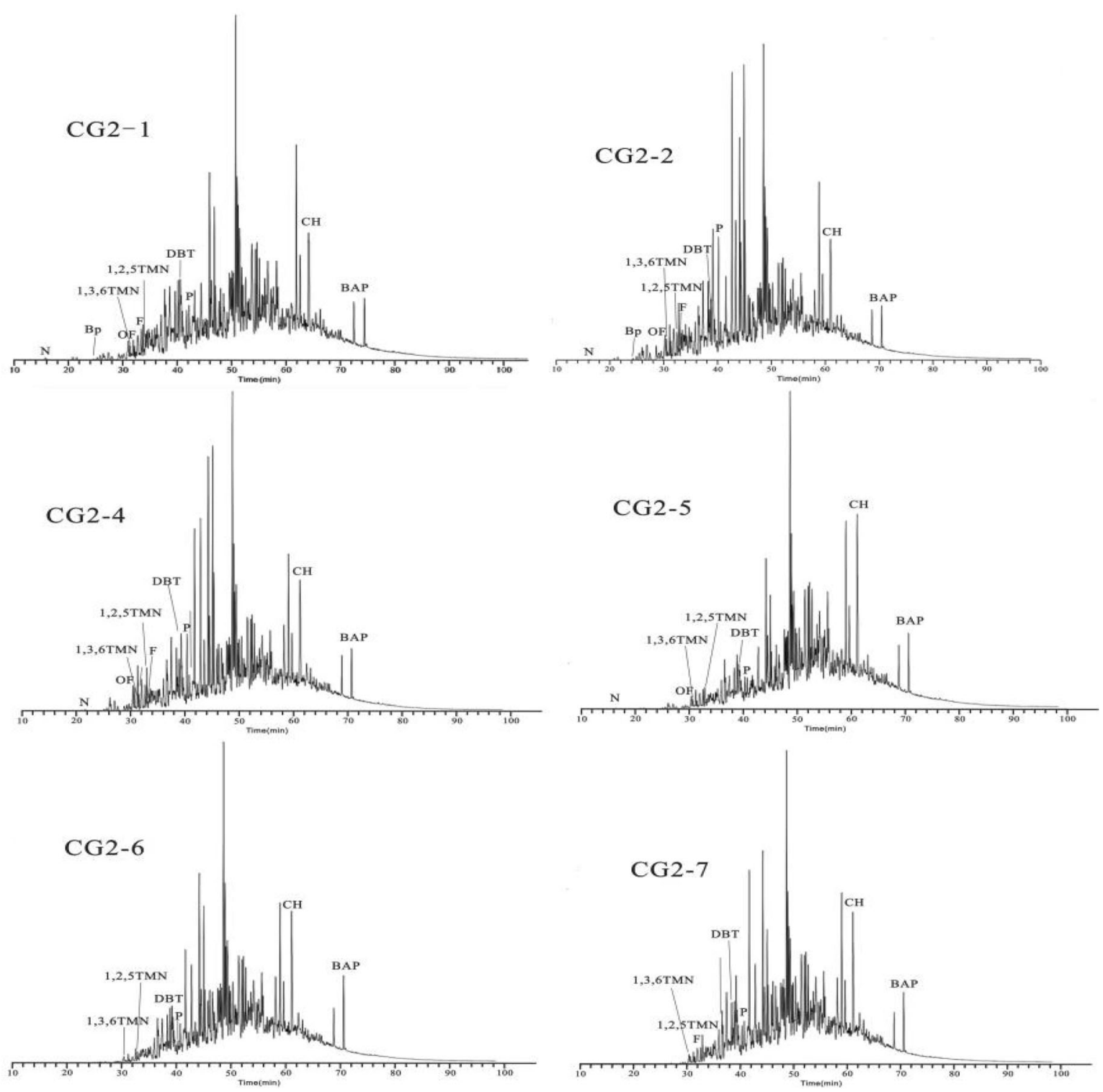

Fig. 3 Mass chromatograms of aromatic hydrocarbons for the samples used

Table 3 Relative abundances of aromatic hydrocarbons and the ratios of biomarkers

\begin{tabular}{|c|c|c|c|c|c|c|c|}
\hline Sample & $\begin{array}{l}\text { Naphthalene series } \\
(\%)\end{array}$ & $\begin{array}{l}\text { Phenanthrene series } \\
(\%)\end{array}$ & $\begin{array}{l}\text { F-OF-SF series } \\
(\%)\end{array}$ & $\begin{array}{l}\text { Chrysene series } \\
(\%)\end{array}$ & $\begin{array}{l}\text { Diphenyl series } \\
(\%)\end{array}$ & $\begin{array}{l}\mathrm{SF} / \\
\mathrm{OF}^{\mathrm{a}}\end{array}$ & $\begin{array}{l}\mathrm{Pr} / \\
\mathrm{Ph}^{\mathrm{b}}\end{array}$ \\
\hline CG2-1 & 11.91 & 43.74 & 9.83 & 4.17 & 0.31 & 6.65 & 1.96 \\
\hline CG2-2 & 9.65 & 43.48 & 19.63 & 2.14 & 0.78 & 8.22 & 1.63 \\
\hline CG2-4 & 11.08 & 53.74 & 16.75 & 3.32 & 0.30 & 14.79 & 1.26 \\
\hline CG2-5 & 8.76 & 45.09 & 8.41 & 12.33 & 0.10 & 12.42 & 2.20 \\
\hline CG2-6 & 5.49 & 50.26 & 10.82 & 9.46 & - & 70.36 & 1.48 \\
\hline CG2-7 & 9.16 & 47.39 & 14.65 & 3.99 & 0.13 & 15.87 & 1.67 \\
\hline
\end{tabular}

F-OF-SF series: fluorine, dibenzothiophene and dibenzofurane series

${ }^{a} \mathrm{SF} / \mathrm{OF}$ : dibenzothiophene/dibenzofurane

${ }^{\mathrm{b}} \mathrm{Pr} / \mathrm{Ph}$ : pristane/phytane ratio 
Table 4 Organic geochemical parameters of aromatic hydrocarbons

\begin{tabular}{llllllllll}
\hline Sample & MNR & TNR $_{1}$ & TNR $_{2}$ & TMNr & TeMNr & MPR & MPI $_{1}$ & $\mathrm{~F}_{1}$ & $\mathrm{~F}_{2}$ \\
\hline CG2-1 & 1.19 & 0.58 & 1.67 & 0.31 & 0.55 & 0.75 & 0.71 & 0.36 & 1.45 \\
CG2-2 & 0.73 & 0.47 & 1.21 & 0.31 & 0.55 & 0.82 & 0.59 & 0.34 \\
CG2-4 & 0.51 & 0.32 & 0.32 & 0.32 & 0.57 & 0.63 & 0.66 & 0.34 \\
CG2-5 & 1.02 & 0.38 & 1.08 & 0.31 & 0.59 & 0.63 & 0.63 & 0.35 & 0.13 \\
CG2-6 & - & 0 & 0.62 & 0 & 0.58 & 0.74 & 0.77 & 0.37 & 0.14 \\
CG2-7 & - & 0.56 & 1.40 & 0.24 & 0.60 & 0.62 & 0.84 & 0.36 & 0.15 \\
\hline
\end{tabular}

$\mathrm{MNR}=2-\mathrm{MN} / 1-\mathrm{MN}$

$\mathrm{TNR}_{1}=2,3,6-\mathrm{TMN} /(1,3,5-\mathrm{TMN}+1,4,6-\mathrm{TMN})$

$\mathrm{TNR}_{2}=(1,3,7-\mathrm{TMN}+2,3,6-\mathrm{TMN}) /(1,3,5-\mathrm{TMN}+1,3,6-\mathrm{TMN}+1,4,6-\mathrm{TMN})$

$\mathrm{TMNr}=1,3,7-\mathrm{TMN} /(1,3,7-\mathrm{TMN}+1,2,5-\mathrm{TMN})$

$\mathrm{TeMNr}=1,3,6,7-\mathrm{TeMN} /(1,3,6,7+(1,2,5,6+1,2,3,5)-\mathrm{TeMN})$

MPR $=2-\mathrm{MP} / 1-\mathrm{MP}$

$\mathrm{MPI}_{1}=1.5 \times(2-\mathrm{MP}+3-\mathrm{MP}) /(\mathrm{P}+9-\mathrm{MP}+1-\mathrm{MP})$

$\mathrm{F}_{1}=(3-\mathrm{MP}+2-\mathrm{MP}) /(3-\mathrm{MP}+2-\mathrm{MP}+1-\mathrm{MP}+9-\mathrm{MP})$

$\mathrm{F}_{2}=2-\mathrm{MP} /(3-\mathrm{MP}+2-\mathrm{MP}+1-\mathrm{MP}+9-\mathrm{MP})$

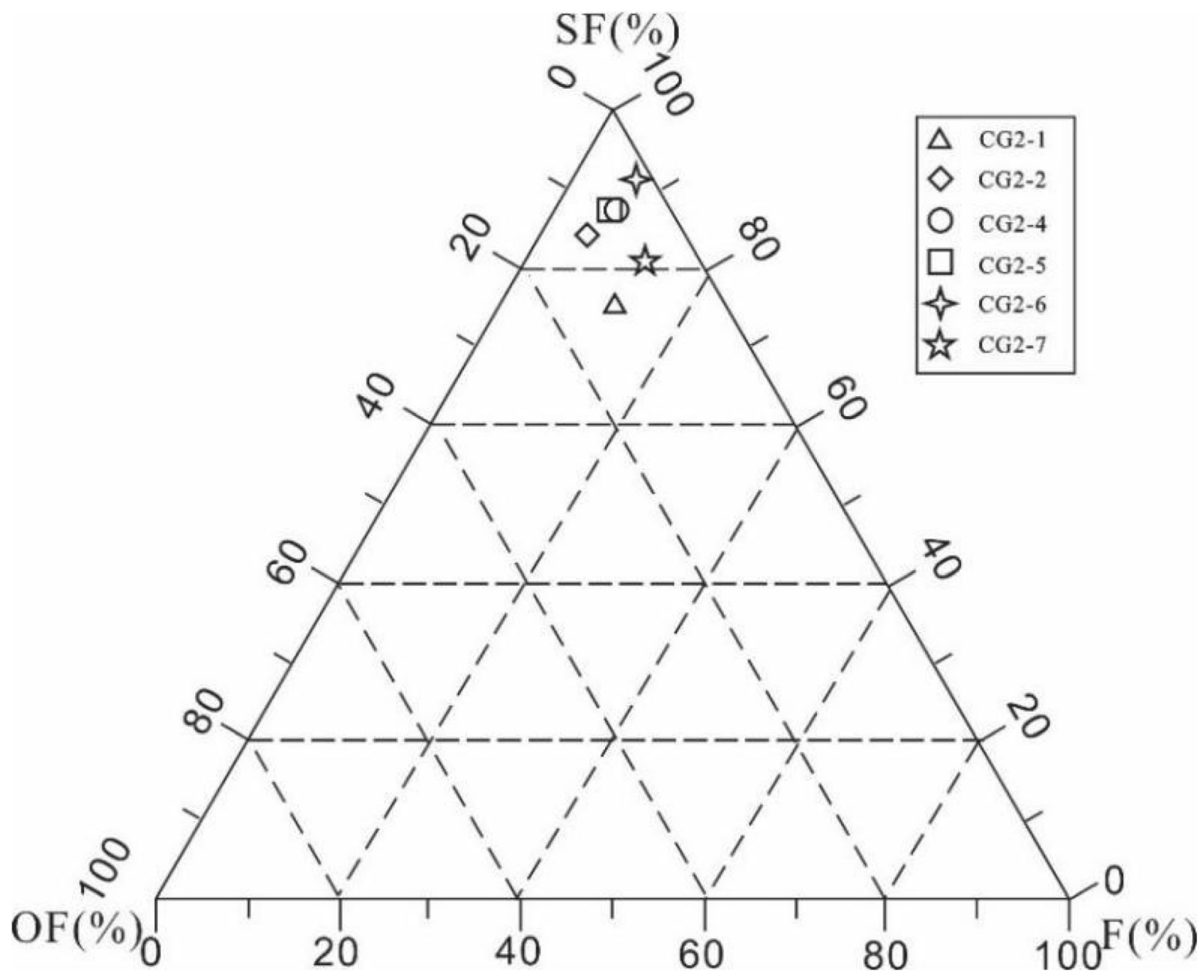

Fig. 4 The triangular diagram of F-OF-SF series of the samples 
environment ( $\mathrm{Li}$ and $\mathrm{He}$ 2008). F, OF, and SF have similar chemical structure and may come from the same precursor. This precursor has a basic skeleton-a five-membered ring. The No.9 carbon on five-membered ring belong to an $\alpha-C$ atom, which is easy to be replaced to SF under reduction conditions and oxidized to OF under weak oxidation or weak reduction conditions (Lin et al. 1987). Previous studies have found it is inaccurate to judge the paleoenvironment during organic matter formation by the single or relative content of $\mathrm{F}, \mathrm{OF}$, and $\mathrm{SF}$. The ratio of SF/OF is more reasonable to instruct the depositional environment, with the marine facies or brackish lakes facies showing the $\mathrm{SF} / \mathrm{OF}$ ratio $>0.7$ (Meng et al. 2011). In this work, the FOF-SF series account for $8.41 \%-19.63 \%$ in total aromatic hydrocarbons. Samples have high SF contents, but low F and $\mathrm{OF}$ contents (Fig. 4). The ratios of SF/OF for test samples vary from 6.65 to 70.36 , suggesting the depositional environment of bark coal were under marine or brackish lakes environment. This is an important depositional condition for the formation of bark coal and is in good agreement with the previous studies that bark coal was deposited under marine environment (Yan et al. 1994; Chen 1995).

The plot of $\sum \mathrm{SF} / \sum(\mathrm{F}+\mathrm{SF})$ versus $\sum \mathrm{OF} / \sum(\mathrm{F}+\mathrm{OF})$ is more sensitive to distinguish the transitional environment (Fig. 5) (Li and He 2008). From Fig. 5, all samples were dropped into $\mathrm{F}$ decrease, OF and SF increase area, suggesting the depositional conditions of the samples are in high salinity environment. CG2-6 and CG2-7 were dropped into high SF content showing strong reduction conditions. This may be due to CG2-6 and CG2-7 two coal seams were most influenced by the marine environment, but it needs more evidence and further discussion.

The dibenzothiophene/phenanthrene (DBT/P) and $\mathrm{Pr} / \mathrm{Ph}$ of crude oil was classified into 5 sedimentary environment and lithology categories according to the results of Hughes et al. (1995) (Table 5). The correlation diagram of the samples used are shown in Fig. 6. As shown in Fig. 6, all samples were fallen within zone 3 , indicating CG2 samples were deposited under marine and lacustrine environment, in accordance with the above results.

3.3.2.4 Diphenyl and chrysene series The contents of diphenyl and chrysene of samples range from $0.10 \%-$ $0.78 \%$ and $2.14 \%-12.33 \%$, respectively (Table 3). Diphenyl seem to be derived from the lignin of higher plants. The high content of diphenyl suggests the terrestrial higher plants dominating in the source input. Chrysene present a negative correlation with naphthalene, implying the chrysene series compounds may be related to the lower aquatic organisms (Tissot et al. 1973). These suggest that the source materials of CG2 coal samples may be influenced by lower aquatic organisms, but is still dominated by higher plants. Chen and Chen (1996) obtained the similar results of source materials of bark coal from the saturated hydrocarbon derived from gas chromatogram.

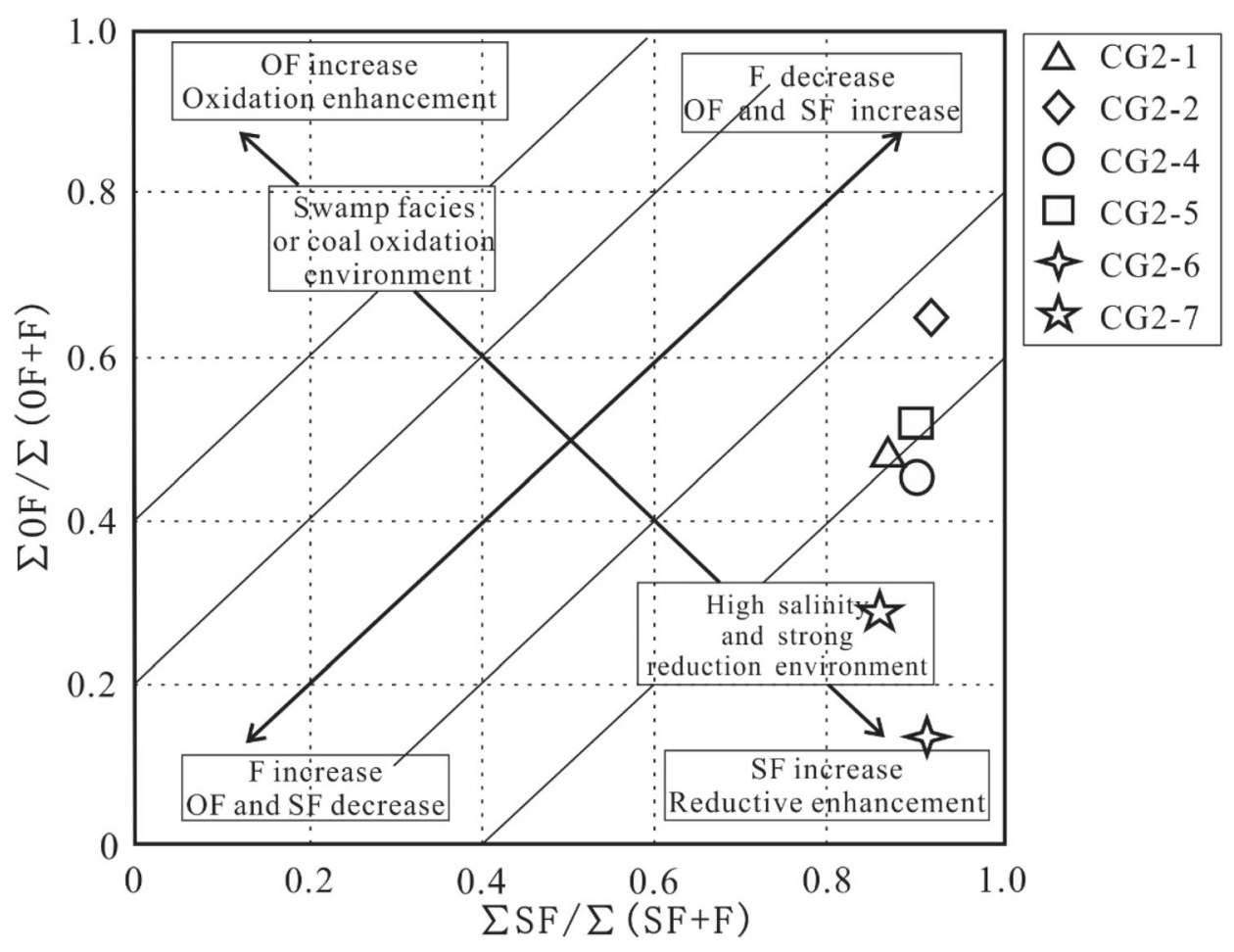

Fig. 5 The $\sum \mathrm{SF} / \sum(\mathrm{F}+\mathrm{SF})$ and $\sum \mathrm{OF} / \sum(\mathrm{F}+\mathrm{OF})$ diagram of the samples. Modified from Li and He (2008) 
Table 5 Correlation between DBT/P and Pr/Ph from different environments (Hughes et al. 1995)

\begin{tabular}{llll}
\hline DBT/P & Pr/Ph & Sedimentary environment & Lithology \\
\hline$>3$ & $<1$ & Marine & Carbonate \\
$1-3$ & $<1$ & Marine and lacustrine (sulfate-rich) & Carbonate and mixed lithology \\
$<1$ & $<1$ & Lacustrine (sulfate-poor) & Variable lithology \\
$<1$ & $1-3$ & Marine and lacustrine & Shale \\
$<1$ & $>3$ & Fluvio/deltaic & Coal and carbonaceous shale
\end{tabular}

\subsection{Saturated hydrocarbons}

Terpenoid are the cyclic isoprene compounds which has strong thermal stability and resistance to microbial degradation. The distributions of homohopane $\left(\mathrm{C}_{31-35}\right)$ obtained from m/z 191 mass fragmentograms by GC-MS analyses of the samples used are depicted in Fig. 7. The homohopane indices $\left(\mathrm{C}_{35} / \mathrm{C}_{31-35}\right)$ could be used to represent the redox potential during organic matter deposition (Peters and Moldowan 1993). The low content of $\mathrm{C}_{35}$ homohopane suggest the samples were deposited under relatively oxic environment. Pristine (Pr) and phytane $(\mathrm{Ph})$ are two important acyclic isoprenoids hydrocarbons which are commonly used to reflect the environmental conditions of sedimentary organic matter (Didyk et al. 1978; Volkman and Maxwell 1986). The values of $\mathrm{Pr} / \mathrm{Ph}$ of samples used vary from 1.26 to 2.20 (Table 3). The low ratios of $\mathrm{Pr} / \mathrm{Ph}$ and $\mathrm{C}_{35} / \mathrm{C}_{31-35}$ homohopane suggest bark coal samples may be deposited under relatively oxic conditions, consistent with the previous researches by Yan and $\mathrm{Li}$ (1958). However, Han et al. (1983) and Chen and Chen (1996) considered the bark coal was formed under a reduction environment during coal formation process. In this study, as demonstrated by the ratios of SF/OF and plot of $\mathrm{Pr} / \mathrm{Ph}$ versus DBT/P, bark coal was thought to deposit under marine or brackish lakes environment. According to the plot of $\sum \mathrm{SF} / \sum(\mathrm{F}+\mathrm{SF})$ versus $\sum \mathrm{OF} / \sum(\mathrm{F}+\mathrm{OF}), \mathrm{CG} 2-$ 6 and CG2-7 two samples seem to deposit under high salinity and strong reduction conditions. This may be due to the strong marine or brackish lakes effect on the two coal seams, which is in accordance with the previous studies that bark coal was influenced by discontinuous marine environment during formation process (Chen and Chen 1996). However, the high inertinite content (14.7\%-41.8\%) of the samples verify that the relatively oxic conditions during bark coal formation is possible (Feng et al. 2019), as

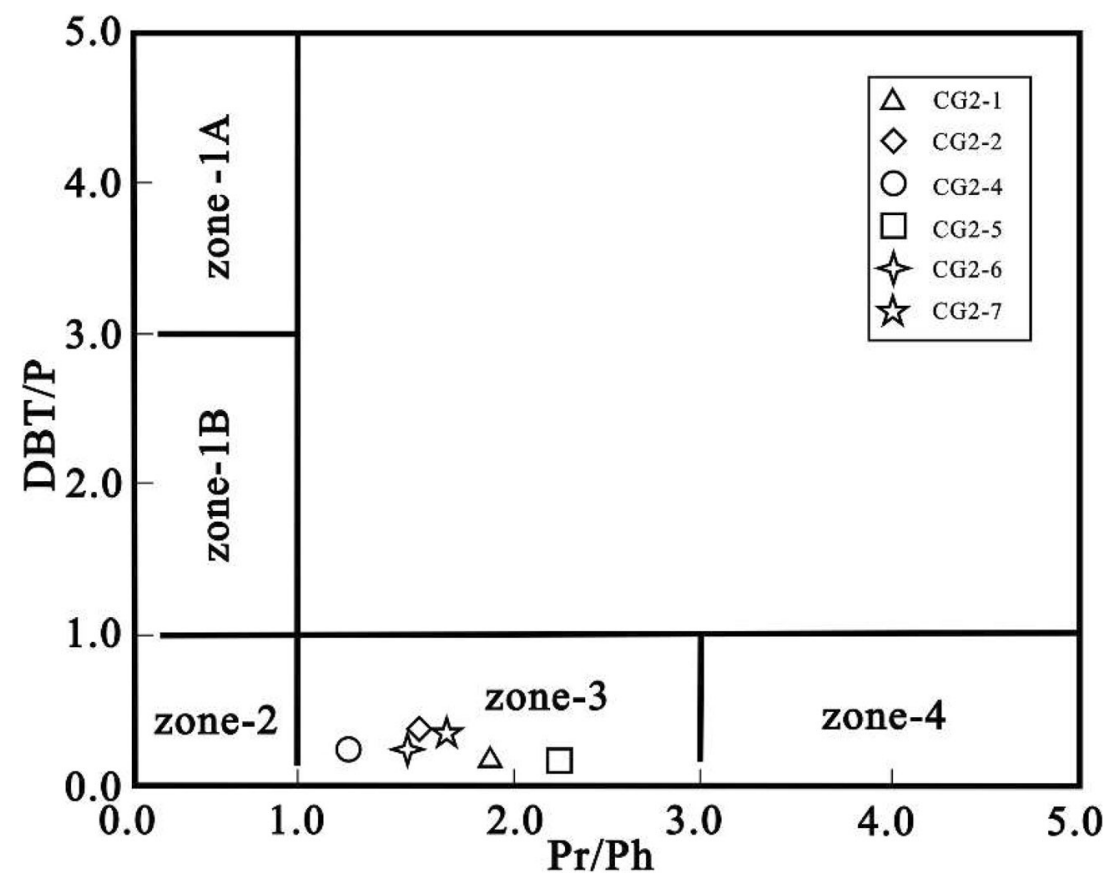

Fig. 6 DBT/P and Pr/Ph diagram for the samples used. Modified from Hughes et al. (1995) 


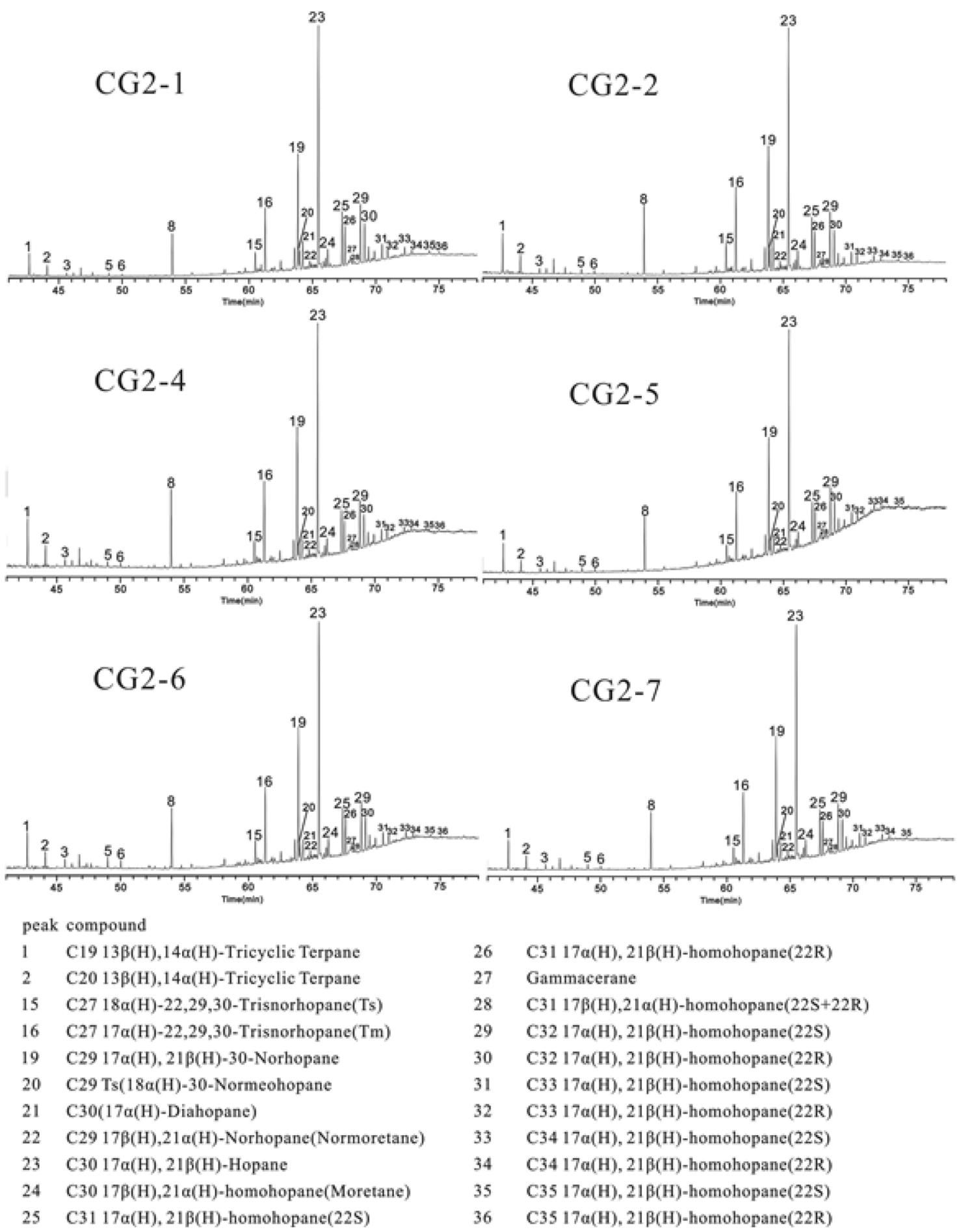

Fig. 7 The m/z 191 mass fragmentograms of saturated hydrocarbon fractions for samples used

discussed in Sect. 3.1. In conclusion, bark coal in Changguang area is considered to form under relatively oxic conditions and influenced by marine or brackish lakes environment. But to further explain the redox conditions and the degree of marine effect on bark coal during formation process, more bark coal samples are needed and various analytical methods are required. 


\section{Conclusions}

Multiple aromatic hydrocarbons and some saturated hydrocarbons indicators as well as the pyrolysis parameters of bark coal in Changguang area were studied by the methods of Rock-Eval pyrolysis, GC and GC-MS analyses, providing indicative significance of sedimentary environment, source materials, and the degree of thermal evolution of bark coal.

(1) According to the $\mathrm{H} / \mathrm{C}-\mathrm{O} / \mathrm{C}$ diagram, all $\mathrm{CG} 2$ samples were classified into Type II kerogen. The values of $T_{\max }$ and $R_{\mathrm{o}}$, and the ratios of alkylated naphthalenes and phenanthrenes suggesting the samples are in the mature stage.

(2) The values of TOC, HI, $\mathrm{S}_{1}+\mathrm{S}_{2}$ from Rock-Eval pyrolysis range from $65.80 \mathrm{wt} \%-87.00 \mathrm{wt} \%$, 170.43-232.89 mg HC/g, and 234-295 mg HC/g TOC, respectively, indicating the samples have good hydrocarbon generation potential.

(3) The high content of naphthalene series compounds indicate an input of terrestrial higher plants during bark coal-forming process. However, the low diphenyl and high chrysene content imply a source of lower aquatic organisms. This indicates the source materials of the samples are predominated by terrestrial higher plants, but mixed with some lower aquatic organisms.

(4) Combined with the biomarkers ( $\mathrm{Pr} / \mathrm{Ph}, \mathrm{C}_{35} / \mathrm{C}_{31-35}$ homohopane), aromatic hydrocarbons (F, OF, SF), maceral compositions, and microscopic characteristics, bark coal is considered to form under relatively oxic conditions and influenced by marine or brackish lakes environment during formation process.

\begin{abstract}
Acknowledgements This research was supported by the National Natural Science Foundation of China for financial support (Research Project No. 41472132), and the Yueqi Youth Scholar Project, China University of Mining \& Technology (Beijing).
\end{abstract}

\section{Compliance with ethical standards}

Conflict of interest No potential conflict of interest was reported by the authors.

Open Access This article is licensed under a Creative Commons Attribution 4.0 International License, which permits use, sharing, adaptation, distribution and reproduction in any medium or format, as long as you give appropriate credit to the original author(s) and the source, provide a link to the Creative Commons licence, and indicate if changes were made. The images or other third party material in this article are included in the article's Creative Commons licence, unless indicated otherwise in a credit line to the material. If material is not included in the article's Creative Commons licence and your intended use is not permitted by statutory regulation or exceeds the permitted use, you will need to obtain permission directly from the copyright holder. To view a copy of this licence, visit http://creativecommons. org/licenses/by/4.0/.

\section{References}

Ameh EG (2019) Geochemistry and multivariate statistical evaluation of major oxides, trace and rare earth elements in coal occurrences and deposits around Kogi east, Northern Anambra Basin, Nigeria. Int J Coal Sci Technol 6(2):260-273

Chen QS (1995) Sedimentary environments of Longtan plant group and Leping coal in Southern China. South China Pet Geol 1(2):28-33

Chen QS, Chen NG (1996) Origin and precursors of late Permian Leping coal in southern China. Mar Origin Pet Geol 1(2):29-33

Dai HW, Chen NS, Liu NQ, Chen WM (1984) Macerals and physicochemical properties of Loping bark coal. J China Coal Soc 7(3):81-87

Didyk BM, Simoneit BRT, Brassell SC, Eglinton G (1978) Organic geochemical indicators of palaeoenvironmental conditions of sedimentation. Nature 272(5650):216-222

Feng S, He J, Tian JJ, Lu XY, Yang B (2019) The characteristic and evolution of coal-forming swamp in Hanshuiquan district, Santanghu coalfield, Xinjiang, NW China, during the Middle Jurassic: evidence from coal petrography, coal facies and sporopollen. Int J Coal Sci Technol 6(1):1-14

GB/T 31391-2015 (2015) Ultimate analysis of coal

GB/T 18340-2010 (2010) Organic geochemical analysis methods for geological samples-part 1: analysis of light crude oil-gas chromatography

GB/T 18602-2012 (2012) Rock pyrolysis analysis

GB/T 19145-2003 (2003) Determation of total organic carbon of sedimentary rock

GB/T 30732 - 2014 (2014) Proximate analysis of coal-instrumental method

Han DX, Ren DY, Guo MT (1983) Origin of bark liptobiolite and its depositional environment of Changguang coalfield, Zhejiang province. Acta Sedimentol Sin 1(4):1-14

Han DX, Ren DY, Wang YB, Jin KJ, Mao HL, Qin Y (1996) Coal petrology of China. China University of Mining \& Technology Press, Xuzhou

Hsieh CY (1933) On lopinite, a new type of coal in China. Bull Geol Soc China 12(1-2):469-490

Hughes WB, Holba AG, Dzou LIP (1995) The ratio of dibenzothiophene to phenanthrene and pristane to phytane as indicators of depositional environment and lithology of petroleum source rocks. Geochimica et Cosmoschimica Acta 59(17):3581-3598

Hunt JM (1996) Petroleum geochemistry and geology, 2nd edn. Freeman, San Francisco

Kvalheim OM, Christy AA, Telnæs N, Bjørseth A (1987) Maturity determination of organic matter in coals using the methylphenanthrene distribution. Geochimica et Cosmoschimica Acta 51(7):1883-1888

Li SF, He S (2008) Geochemical characteristics of dibenzothiophene, dibenzofuran and fluorene and their homologues and their environmental indication. Geochimica 37(1):45-50

Lin RZ, Wang PR, Dai YJ (1987) Petroleum geo-chemical significance of polycyclic aromatic hydrocarbons in fossil fuels. In: Collection on organic geochemistry. Geological Press, Beijing, pp 129-140

Meng JH, Liu LF, Zhang M, Wang Y (2011) Indicative function of aromatic hydrocarbon include oil on depositional environment. J China Univ Min Technol 40(6):901-907 
Peters KE, Moldowan JM (1993) The biomarker guide: interpreting molecular fossils in petroleum and ancient sediments. PrenticeHall, Englewood Cliffs

Powell TG, Boreham CJ (1994) Terrestrially sourced oils: where do they exist and what are our limits of knowledge? A geochemical perspective. Geol Soc Lond Special Publ 77(1):11-29

Radke M, Welte DH, Willsch H (1982) Geochemical study on a well in the Western Canada Basin: relation of the aromatic distribution pattern to maturity of organic matter. Geochimica et Cosmoschimica Acta 46(1):1-10

Ren DY, Gao QC, Liu XS, Wang M (1963) The petrographic characteristics and quality characteristics of coal-bearing of Leping formation in Leping depression, Jiangxi province. In: Proceedings of the 32nd annual meeting of geological society of China monograph of stratigraphy and coal geology, pp 124-128

Singh PK, Singh VK, Singh MP, Rajak PK (2017) Petrographic characteristics and paleoenvironmental history of Eocene lignites of Cambay basin, Western India. Int J Coal Sci Technol 4(3):214-233

Sun XG (2002) The optical features and hydrocarbon-generating model of "barkinite" from Late Permian coals in South China. Int J Coal Geol 51(4):251-261
SY/T 5779-2008 (2008) Analytical methods of hydrocarbons in petroleum and sediment by gas chromatography. Petroleum Industrial Press, Beijing, pp 1-16

Tissot B, Durand B, Espitalie J, Combaz A (1973) Influence of nature and diagenesis of organic matter in formation of petroleum. AAPG Bull 58(3):499-506

Volkman JK, Maxwell JR (1986) Acyclic isoprenoids as biological markers. In: Johns RB (ed) Biological markers in the sedimentary record. Elsevier, New York, pp 1-42

Wang SJ, Liu XW, Song LJ (1998) The coal-forming plants of lopinite and genesis of barkinite. J China Coal Soc 23(3):231-234

Yan JF, Li GY (1958) Coalfield geology of near Leping and "Leping coal". Acta Geol Sin 38(3):343-368

Yan YJ, He HM, Xi YL, Huang WT (1994) The composition, behavior and utilization of Leping coal in Jiangxi Province. Jiangxi Bureau of Coalfield Geology 223 Geological Team

Yang WL, Li YK, Gao RQ, Guo QF (1981) Types and evolution model of continental source materials in the Songliao Basin. Sci Sin 24(8):1000-1008

Zhu YM, Zhang HB, Fu JM, Sheng GY (1998) Distribution and composition of aromatic hydrocarbon in various oils from Tarim basin. Acta Pet Sin 19(3):33-37 